Advances in Intelligent Systems and Computing 490

Christopher Schlick

Stefan Trzcieliński Editors

Advances in Ergonomics

of Manufacturing:

Managing the

Enterprise of the Future

Proceedings of the AHFE 2016

International Conference on Human

Aspects of Advanced Manufacturing,

July 27-31, 2016, Walt Disney World ${ }^{\circledR}$,

Florida, USA

算 Springer 


\title{
Group Support Systems Features and Their Contribution to Technology Strategy Decision-Making: A Review and Analysis
}

\author{
Cláudio Santos, Madalena Araújo and Nuno Correia
}

\begin{abstract}
Collective decision-making processes require careful design considerations in organizations. On one hand, the inclusion of a greater number of actors contribute to a wider knowledge base, on the other, it can become a diffuse process and be distorted from the principles initially established. This paper observes a specific collective decision making process in organizations-technology strategy formulation - and, through a critical review of the literature, analyzes how the advances in features of group support systems support improvements in different stages of this process. This paper also discusses the implications of GSS appropriation in group dynamics.
\end{abstract}

Keywords Technology strategy - Group support systems • Review • Decision-Making

\section{Introduction}

The growing globalization of businesses is driving important changes in the many ways people communicate. Large corporations have to deal with the particularities, be them geographical, economic and cultural, of business units of various locations. This issue is also faced, to a certain degree, by Small and Medium Enterprises

\footnotetext{
C. Santos $(\bowtie) \cdot$ M. Araújo

Department of Production and Systems, School of Engineering, University of Minho, Azurem Campus, 4804-533 Guimarães, Portugal

e-mail: claudio.santos@dps.uminho.pt

M. Araújo

e-mail: mmaraujo@dps.uminho.pt

N. Correia

Institute of Mechanical Engineering and Industrial Management, FEUP Campus, 4200-465 Porto, Portugal e-mail: ncorreia@inegi.up.pt 
(SMEs) which have, for example, to accommodate divergent requirements of several customers and manage suppliers with different capabilities.

With respect to group decision-making that requires the analysis of sensitive topics, such as the role of leadership and aspects of organizational culture, the approach chosen may have a determinant role in the effectiveness of group meetings. In an attempt to overcome these issues, Group Support Systems (GSS) are making unprecedented contributions to improve the communications between and within organizations and thus, in collaborative decision-making.

In the specific case of decisions involved in the formulation of a technology strategy, these may be compromised by: (1) divergent opinions arising from the functional areas involved in the process (technical, marketing, production departments and others) (2) different cultural backgrounds and (3) uncertainty and ambiguity. Despite its undeniable importance for the exchange of ideas and problem solving, the dynamics imposed in group meetings may lead to job dissatisfaction [1] and higher costs derived from excessive time devoted to meetings [2]. In this paper, we explore how different features of GSS have been contributing to improve strategic decision-making in organizations.

The remainder of this paper is structured as follows: Sect. 2 presents the literature review on the topics of technology strategy and group support system. Section 3 describes the research methods used in this study. Section 4 discusses the potential contribution to the technology strategy formulation process and Sect. 5 presents the conclusions.

\section{Literature Review}

\subsection{Technology Strategy: Stages and Tools}

The management of technology is understood as a fundamental cornerstone of the competiveness of companies. As an integral process of managing technology [3] technology strategy is defined as the process through which organizations develop and leverage technological resources to exploit market opportunities [4, 5].

The enactment of a technology strategy is a complex task for organizations for a variety of reasons, one of them being the relative irreversibility of technological investments. Such investments are made in a context of high uncertainty, as it is considered a period of strategic positioning for organizations, when considerable financial commitments have already been made [6].

The content of technology strategy concerns the required decisions that constitute a technology strategy program [7]. A review of the most prominent decisions is summarized in Table 1.

A large number of frameworks have been proposed to support the formulation of a technology strategy in business environments [7-13], which in essence characterize a structured methodology to conduct the process. Technology strategy 
Table 1 A review of technology strategy decisions

\begin{tabular}{|c|c|c|c|c|c|}
\hline Decisions & {$[8]$} & {$[10]$} & {$[12]$} & {$[16]$} & {$[7]$} \\
\hline Selection of technologies & $\mathrm{X}$ & $\mathrm{X}$ & $\mathrm{X}$ & $\mathrm{X}$ & $\mathrm{X}$ \\
\hline Technology acquisition mode & & $\mathrm{X}$ & $\mathrm{X}$ & $\mathrm{X}$ & $\mathrm{X}$ \\
\hline Timing of introduction & & $\mathrm{X}$ & $\mathrm{X}$ & & $\mathrm{X}$ \\
\hline $\begin{array}{l}\text { Organization and management approach of technology } \\
\text { and innovation }\end{array}$ & & $\mathrm{X}$ & & & $\mathrm{X}$ \\
\hline Organization of technology intelligence efforts & & $\mathrm{X}$ & & & \\
\hline $\begin{array}{l}\text { Identification and exploitation of technological } \\
\text { interrelationships }\end{array}$ & & $\mathrm{X}$ & & & \\
\hline $\begin{array}{l}\text { Selection, evaluation, resource allocation and control of } \\
\text { projects }\end{array}$ & & $\mathrm{X}$ & & & \\
\hline Technology availability and feasibility & & & & $\mathrm{X}$ & \\
\hline Process to ensure best return of investment & & & & $\mathrm{X}$ & \\
\hline Required technological competences and capabilities & & & & & $\mathrm{X}$ \\
\hline Investment level in technological developments & & & & & $\mathrm{X}$ \\
\hline
\end{tabular}

frameworks consists of two basic elements [14]: activities and tools. Through an extensive review of proposed frameworks, Santos [15] argues that the technology strategy formulation is consolidated in five core activities, each of them supported by a wide range of tools and techniques: internal analysis, external analysis, generation, selection and monitoring.

The internal analysis activity concerns the identification and assessment of the technological competences and capabilities inside the organization. The external analysis is related with the process aimed at identifying possible technological trajectories, their impacts in the industry and in events that may influence these patterns. The generation activity is related to the activities involved in generating technology project ideas, based upon the findings from the internal and external analysis and in specific pieces of information required in the ideas generation process (patents, technology suppliers, etc.). Selection activity addresses how the generated technology project ideas are going to be selected for implementation within technology investment budgets. This should also consider how technology is going to be sourced (developed in-house, in collaboration or acquired externally). Finally, the monitoring activity is related to the control and oversight of the project and the learning from theses vis-a-vis the initial goals set, turning the enactment of a strategy a cyclical process in the long-term.

The tools and techniques used in each activity play an important role in supporting the definition, evaluation and decision-making process. The complexity inherent in the requirement of studying several areas of knowledge to define a technology strategy may favor the integration of different tools and techniques to grasp the best features of each one and thus support the development of a more robust framework [3]. On another aspect, the exchange of ideas and communication of guidelines offers a good opportunity for the development of group support systems (GSS) that support the development of a technology strategy inside organizations. 


\subsection{Group Support Systems}

Group meetings are often arranged so that a group of individuals can share ideas, make decisions, solve problems and communicate within organizations. It has been defined as a "a focused interaction of cognitive attention, planned or chance, where people agree to come together for a common purpose, whether at the same time and same place, or at different times in different places" [17]. Their existence is based on the principle that collective knowledge supports improved decision-making $[18,19]$.

The contribution of group meetings to decision-making has been extensively discussed in the literature. Its overuse may lead to unproductive group meetings [20], job dissatisfaction [1] and high costs, either due to the time directly devoted to the meetings, or to opportunity costs, i.e. time wasted that could be used in more productive activities $[2,21]$. On the other hand, an excessive reduction of the number of meetings limit access to needed information and may also cause employees' job dissatisfaction [2].

The most frequent mode for conducting group meetings is face-to-face. Despite enabling a comprehensive media for exchanging non-verbal communications, face-to-face meeting have numerous problems [22]: obtaining meaningful responses deriving from the inability of some individuals to express their ideas publicly and because of time limitations; limitations with group size, which normally reduces the opportunity of an individual to make his/her contribution and costs associated with the time and resources required in the schedule, coordination and realization of group meetings.

The advent of advanced information and communication technologies (ICT) is having a considerable impact in the way people communicate inside organizations. In this domain, Group Support Systems (GSS) is an electronic meetings system technology consisted of a network of computers connected to support group meetings and collaborative work [23, 24].

GSS may include a number of tools and techniques designed to facilitate several tasks in group discussions, such as problem definition, explorations of issues, consensus building, group writing, activity coordination, knowledge sharing and accumulation, data and decision analysis [25]. GSS may also use a divergent information gathering software in order to collect a large number of ideas quickly [26].

Three basic features characterize GSS: asynchronous communication, anonymity and collective memory - the access to previous participants' inputs [27]. GSS are expected to benefit group meetings in the sense it may free individuals from group conformity and scrutiny [28]. Despite such advantages, some studies indicate that GSS may have lower performance in particular issues, namely in decision speed [29] and effectiveness of leadership and coordination competence over time [30] and group cohesion [31]. GSS may also be embedded with group management techniques such as the Delphi method and Nominal Group Technique (NGT) to improve the coordination and effectiveness of group meetings [32].

Nowadays, GSS are having a significant impact in the socio-technical designs of organizations, especially in larger groups, where GSS has proved to be most 
effective [33]. There is also an increasing usage of the structure of social networking in GSS [34, 35].

The objective of this study is to analyze the contribution of GSS in technology strategy formulation. This paper differs from the study developed by Torkkeli and Tuominen [36] which examined the role of technology selection in managing core competencies and identified several characteristics of GSS that may contribute to fulfill the requirements of this process. In this study, a further level of analysis is included in the sense that inherent characteristics of activities involved in an organization process - technology strategy formulation-are analyzed and contrasted with the potential contributions from the adoption of GSS.

\section{Research Methods}

The research method used in this paper is based on the review of existing literature about GSS with focus on a specific organizational process - technology strategy formulation. A technology strategy framework composed of a number of activities is used as lens for analyzing potential contributions from GSS features.

\section{GSS in Technology Strategy Formulation}

This section presents a review and analysis of the use of GSS in different stages of the technology strategy formulation process, as evidenced in the literature review section. It highlights specific features of GSS and their potential contribution to each of the aforementioned activity.

\subsection{Activities and Applications of GSS}

GSS are primarily useful for quickly gathering inputs from multiple participants, disseminating this information and in providing structure for collective decision-making. Table 2 presents a review of applications of GSS in different activities of technology strategy formulation. A discussion on each of the activity is provided below.

The activity of assessing internal capabilities deals not only with technical competencies, but also with management skills, and often involves the discussion of sensitive issues such as those related with the leadership exerted by top management. This discussion may lead to internal divisions and biased assessments. Anonymity enabled by GSS may exempt employees from social pressures and dominant personalities, thus contributing with more engagement and more accurate assessments of internal capabilities. In terms of tools, internal audits have been used 
Table 2 Technology strategy activities and GSS applications

\begin{tabular}{l|l|l}
\hline $\begin{array}{l}\text { Technology strategy } \\
\text { activities }\end{array}$ & $\begin{array}{l}\text { Examples of } \\
\text { applications }\end{array}$ & GSS features \\
\hline Internal analysis & {$[37]$} & Asynchronous communication, anonymity, group memory. \\
\hline External analysis & {$[38-42]$} & $\begin{array}{l}\text { Consensus building, collaboration, electronic } \\
\text { documentation, moderation/facilitation, asynchronous } \\
\text { communication, descriptive statistics. }\end{array}$ \\
\hline Generation & {$[43,44]$} & $\begin{array}{l}\text { Group memory, asynchronous communication, } \\
\text { moderation/facilitation, proposal submission. }\end{array}$ \\
\hline Selection & {$[45-47]$} & $\begin{array}{l}\text { Group memory, consensus building, and asynchronous } \\
\text { communication. }\end{array}$ \\
\hline Monitoring & {$[48]$} & Group memory. \\
\hline
\end{tabular}

as tools for organizations to self-assess their technological capabilities and to analyze whether the conditions for managing technological innovation are present in the organization. The technological innovation audit proposed by Santos et al. [37] is embedded with the Real Time Delphi method [49] and enables the anonymous participation of employees involved in an organization's technological innovation process in the internal capabilities evaluation. Additionally, group memory is accessible in the sense that participants of the audit can visualize and reply to comments from others, which can contribute to the convergence of judgments towards consensus building.

The external analysis is being increasingly supported by ICT tools. In fact, the results from a survey with foresight experts points to a greater use of ICT in foresight processes and a transition from standard information gathering functionalities to the interpretation of this information for strategy making [50].

The context-based or open foresight [51] is an emerging foresight paradigm that puts more emphasis in communication and creativity among relevant stakeholders inside organizations. In line with this paradigm, GSS may contribute with greater collaboration among a larger number of actors with different perspectives, for raising a higher number of ideas and validating them [40], thus supporting communication and gathering of anonymous feedback and their aggregation in collective insights about technological, economic and societal developments [38] and in the establishment of rules of order in decisions through facilitated group discussions [39]. The web-based system proposed by Spithourakis et al. [42] combines features of forecasting, such as descriptive statistics, with the "soft" factors of foresight to improve user experience and gather a better knowledge about a problem.

The generation activity is, perhaps, the most dependent on the creativity of involved actors. Through enabling group memory, a repository of ideas is continuously and collectively created for proposal submission [43] and concepts generation [44]. When coupled with technology intelligence systems [52, 53], the generation activity can benefit with greater analytical content by keeping an extensive database that gathers, analyzes and disseminates relevant information 
about new technologies, patents, standards, regulations, trends and others to participants in the innovation process of an organization.

The selection activity is typically a GSS embedded with a decision-making procedure, however, GSS which merges external analysis and selection activities have also been proposed [39]. According to Bozdağ and colleagues [54], the selection of technology projects is a multi-dimensional and complex task which involves considerable uncertainty, and therefore should include non-quantifiable, intangible criteria, in which human reasoning is critical and GSS can leverage this through intensive group interaction. The model proposed by Zandi and Tavana [46] also include subjective criteria and considers the interdependencies between information technology (IT) projects. An organizational decision support system (ODSS) is proposed by Tian et al. [45] to address two particularities of typical R\&D project selection: as a typical multi-stage decision-making process and the involvement of groups of people from different organizational units. On the other hand, Choudhury et al. [47] highlights the disadvantages of asynchronous communication in building consensus and adopts the concept of consensus measure to improve on the group interaction process and replace the role of a moderator.

Compared to the previous activity, monitoring has received less attention for GSS development, which can be partially explained by being often performed by management control groups instead of being a bottom-up process. Dennis et al. [48???] has recalled the importance of group memory for retrieving information about past decisions and goals initially set to compare with performance of the strategy under implementation.

\subsection{Contributions for Group Dynamics}

Besides removing geographical and time restrictions in communications (through asynchronicity and group memory), GSS provide a number of features that improve the way groups of people can interact towards a common goal. In a review of various studies that compares asynchronous GSS and face-to-face group meetings, Tung and Turban [55] identified a number of implications of adopting GSS in group dynamics: increased choice shift among participants which contributed to achieving consensus; improved conflict management where disagreements and conflicts were more easily overcome in GSS meetings, focus of participants, with respect to task orientation and productivity and performance, more specifically concerning the quality of ideas generated by groups of people.

In a longitudinal study aimed to offset likely biases in the evaluation of GSS, Reinig and Shin [56] selected three issues commonly associated with face-to-face meetings - production blocking, free riding and sucker effect-and found that the adoption of GSS improves group cohesion, self-reported learning and affective reward, although they could not conclude on the individual level of influence of each of the analyzed features of GSS (anonymity and simultaneity). 
The nature of the tasks being performed has natural implications in the use of GSS. If consensus building is the ultimate goal of the process, GSS should be not be used in stages when factual information is exchanged, but only when decision options are being analyzed and selected [57]. Concerning the information being shared in regular and non-regular or role-assigned GSS meetings, Vathanophas and Liang [58] found that in the first, participants tend to use more commonly shared information while in the latter unique or individually held information are more shared to support collective knowledge homogenization of groups with different fields and levels of expertise. Minorities tend to experience greater uncertainty, greater conformity, lower satisfaction and produce lower quality decisions in groups that share common perceptions and beliefs and when non-anonymous communications are enabled [59].

Over a decade ago, Shim et al. [60] provided a research agenda for GSS in which they highlighted the need to address incomplete data and qualitative insights from participants through the infusion of intelligence systems and methods in GSS. Now, with the emergence of advanced artificial intelligence, there are several opportunities for GSS in organizations. On the other hand, Ackerman and Eden [61] warn about the dangers of technological opportunism and argues that mixed techniques which incorporate single user and manual methods should be promoted as to complement divergent thinking - through the rapid generation and proposal of ideas supported by GSS technologies - with human facilitated convergent thinking for adequate and inclusive decision-making. This aligns with the findings of Limayem et al. [62] which indicated that the assimilation of GSS structure should be accompanied by tailored training and decisional guidance.

\section{Conclusions}

The socio-technical design of organizations has been strongly influenced by advances in GSS. The massive use of social networking is an evidence that GSS has the potential of drastically changing how groups of people make decisions [34, 35]. This paper presents an extensive review and an analysis of GSS literature, with emphasis on GSS applications in different stages of the technology strategy making process.

In literature, while much focus is being put in observing the determinants of information sharing and adoption of GSS, much has been left untreated with respect to implications in different organizational settings and task specificities. In this paper, we expect to fill this latter gap by relating features of GSS, derived from literature, with the activities and stages of a specific decision-making process in organizations - technology strategy formulation. The characteristics of such activities are analyzed in order to specify how groups of people analyze information and make decisions collectively, and thus relate such issues to the potential contributions from the implementation of GSS. Additionally, the way GSS influence group dynamics towards achieving greater meetings' results were also highlighted. 
We expect that, with this study, some design principles for GSS for technology strategy formulation in organizations can be identified. Further work needs to be done to generalize these findings, by analyzing other organizational decision-making practices.

Acknowledgments This research was supported by Fundação para a Ciência e Tecnologia (SFRH/ BD/ 33727/ 2009), within the framework of the MIT Portugal Program.

\section{References}

1. Rogelberg, S.G., Allen, J.A., Shanock, L., Scott, C., Shuffler, M.: Employee satisfaction with meetings: a contemporary facet of job satisfaction. Hum Resour Manage 49, 149-172 (2010)

2. Rogelberg, S.G., Shanock, L.R., Scott, C.W.: Wasted time and money in meetings: increasing return on investment. Small Gr Res 43, 236-245 (2011)

3. Phaal, R., Farrukh, C.J.P., Probert, D.R.: Technology management tools: concept, development and application. Technovation 26, 336-344 (2006)

4. Zahra, S.A.: Technology strategy and financial performance: examining the moderating role of the firm's competitive environment. J Bus Ventur 11, 189-219 (1996)

5. Chiesa, V., Manzini, R.: Towards a framework for dynamic technology strategy. Technol Anal Strateg Manag 10, 111-129 (1998)

6. Mitchell, G.R.: Alternative frameworks for technology strategy. Eur J Oper Res 47, 153-161 (1990)

7. Burgelman, R.A., Christensen, C.M., Wheelwright, S.C.: Strategic management of technology and innovation. McGraw Hill/Irwin, Boston (2003)

8. Porter, M.E.: Competitive advantag: creating and sustaining superior performance. The Free Press, New York (1985)

9. Ford, D.: Develop your technology strategy. Long Range Plann 21, 85-95 (1988)

10. Hax, A.C., Nicolas, S.: Majluf: the strategy concept and process: a pragmatic approach. Prentice Hall, Englewood Cliffs, N.J (1991)

11. du Preez, G.T., Pistorius, C.W.I.: Technological threat and opportunity assessment. Technol Forecast Soc Change 61, 215-234 (1999)

12. Chiesa, V.: R\&D strategy and organization: managing technical change in dynamic environments. Imperial College Press, London (2001)

13. Davenport, S., Campbell-Hunt, C., Solomon, J.: The dynamics of technology strategy: an exploratory study. R\&D Manag 33, 481-499 (2003)

14. Centidamar, D., Phaal, R., Probert, D.: Technology management: activities and tools. Palgrave Macmillan (2010)

15. Santos, C.: Development of an integrated framework for the definition of technology strategies. PhD thesis, University of Minho, Portugal (2014)

16. Lindsay, J.D.: Technology mamagement audit. Cambridge Strategy Publications Limited (2001)

17. Romano, N.C., Nunamaker, J.F.: Meeting analysis: Findings from research and practice. In: Proceedings of 34th Annual International Conference on System Science, pp. 1-13 (2001)

18. Martz, W.B., Vogel, D.R., Nunamaker, J.F.: Electronic meeting systems. Results from the field. Decis Support Syst 8, pp. 141-158 (1992)

19. Craig, S.B.: Leadership in Organizations (7th edition) by Gary Yukl. Pers Psychol 64, 1056-1059 (2011)

20. Green, W.A., Lazarus, H.: Are today's executives meeting with success? J Manag Dev 10, 14-25 (1991) 
21. Lehmann-Willenbrock, N., Kauffeld, S.: Meetings matter: effects of team meetings on team and organizational success. Small Gr Res 43, 130-158 (2012)

22. Dowling, K.L., St. Louis, R.D.: Asynchronous implementation of the nominal group technique: is it effective? Decis Support Syst 29, 229-248 (2000)

23. Dennis, A.R., George, J.F., Jessup, L.M., Nunamaker Jay F.J., Vogel, D.R.: Information technology to support electronic meetings. Manag. Inf. Syst. 12, pp. 591-624 (1988)

24. Chudoba, K.M., Warson-Manheim, M.B., Crowston, K., Lee, C.S.: Participation in ICT-Enabled Meetings. J Organ End User Comput 23, 15-36 (2011)

25. Ngwenyama, O.K., Bryson, N., Mobolurin, A.: Supporting facilitation in group support systems: techniques for analyzing consensus relevant data. Decis Support Syst 16, 155-168 (1996)

26. Adkins, M., Burgoon, M., Nunamaker, J.F.: Using group support systems for strategic planning with the United States Air Force. Decis Support Syst 34, 315-337 (2003)

27. Nunamaker, J.F., Dennis, A.R., Valacich, J.S., Vogel, D., George, J.F.: Electronic meeting systems. Commun ACM 34, 40-61 (1991)

28. Shirani, A., Aiken, M., Paolillo, J.G.: Group decision support systems and incentive structures. Inf Manag 33, 231-240 (1998)

29. Gallupe, R.B., McKeen, J.D.: Enhancing Computer-Mediated Communication: An experimental investigation into the use of a Group Decision Support System for face-to-face versus remote meetings. Inf Manag 18, 1-13 (1990)

30. Burke, K., Chidambaram, L., Locke, J.: Evolution of relational factors over time: a study of distributed and nondistributed meetings. In: Proceedings of the Twenty-Eighth Hawaii International Conference on System Sciences, pp. 14-23. IEEE (1995)

31. Chidambaram, L., Bostrom, R.P., Wynne, B.E.: A longitudinal study of the impact of group decision support systems on group development. J Manag Inf Syst 6, 7-25 (1990)

32. Beruvides, M.G.: Group decision support systems and consensus building: Issues in electronic media. Comput Ind Eng 29, 601-605 (1995)

33. Briggs, F.N.J., Mittleman, R.O., Vogel, D.D., Balthazard, P.A.: Lessons from a dozen years of group support systems research: A discussion of lab and field. J. Manag. Inf. Syst. 13, 163 (1996)

34. Antunes, F., Costa, J.P.: Integrating decision support and social networks. Adv Human-Computer Interact 2012, 1-10 (2012)

35. Chang, W., Lo, Y.: A social network based group decision support system. Int J Mob. Commun 10, 41-64 (2011)

36. Torkkeli, M., Tuominen, M.: The contribution of technology selection to core competencies. Int J Prod Econ 77, 271-284 (2002)

37. Santos, C., Araújo, M., Correia, N.: Convergence of judgments in technological innovation audit: A case study application in a sheet metal processing equipment manufacturer. In: Proceedings of Technology Management for Emerging Technologies PICMET'12, pp. 18921903. IEEE (2012)

38. Salo, A., Gustafsson, T.: A group support system for foresight processes. Int J Foresight Innov Policy 1, 249-269 (2004)

39. Bañuls, V.A., Salmeron, J.L.: Scope and design issues in foresight support systems. Int J. Foresight Innov Policy 7, 338-351 (2011)

40. Weigand, K., Flanagan, T., Dye, K., Jones, P.: Collaborative foresight: Complementing long-horizon strategic planning. Technol Forecast Soc Change 85, 134-152 (2014)

41. Durst, C., Durst, M., Kolonko, T., Neef, A., Greif, F.: A holistic approach to strategic foresight: a foresight support system for the german federal armed forces. Technol Forecast Soc Change 97, 91-104 (2015)

42. Spithourakis, G.P., Petropoulos, F., Nikolopoulos, K., Assimakopoulos, V.: Amplifying the learning effects via a forecasting and foresight support system. Int J Forecast 31, 20-32 (2015)

43. Satzinger, J.W., Garfield, M.J.: The creative process: the effects of group memory on individual idea generation. J Manag Inf Syst 15, 143-161 (1999) 
44. Yilmaz, S., Daly, S.R., Christian, J.L., Seifert, C.M., Gonzalez, R.: Can experienced designers learn from new tools? A case study of idea generation in a professional engineering team. Int J Des Creat Innov 2, 82-96 (2014)

45. Tian, Q., Ma, J., Liang, J., Kwok, R.C.W., Liu, O.: An organizational decision support system for effective R\&D project selection. Decis Support Syst 39, 403-413 (2005)

46. Zandi, F., Tavana, M.: A multi-attribute group decision support system for information technology project selection. Int J Bus Inf Syst 6, 179-199 (2010)

47. Choudhury, A.K., Shankar, R., Tiwari, M.K.: Consensus-based intelligent group decision-making model for the selection of advanced technology. Decis Support Syst 42, 1776-1799 (2006)

48. Dennis, A.R., George, J.F., Jessup, L.M., Nunamaker Jay F.J., Vogel, D.R.: Information technology to support electronic meetings. Manag. Inf. Syst. 12, pp. 591-624 (1988)

49. Gordon, T., Pease, A.: RT Delphi: an efficient, round-less almost real time Delphi method. Technol Forecast Soc Change 73, 321-333 (2006)

50. Keller, J., von der Gracht, H.A.: The influence of information and communication technology (ICT) on future foresight processes-Results from a delphi survey. Technol Forecast Soc Change 85, 81-92 (2014)

51. Miemis, V., Smart, J., Brigis, A.: Open Foresight J Futur Stud 17, 91-98 (2012)

52. Savioz, P., Heer, A., Tschirky, H.P.: Implementing a technology intelligence system: key issues. In: International Conference on Management of Engineering and Technology PICMET01. pp. 198-199 (2001)

53. Lichtenthaler, E.: Technological change and the technology intelligence process: a case study. J Eng Technol Manag 21, 331-348 (2004)

54. Bozdağ, C.E., Kahraman, C., Ruan, D.: Fuzzy group decision making for selection among computer integrated manufacturing systems. Comput Ind 51, 13-29 (2003)

55. Tung, L., Turban, E.: A proposed research framework for distributed group support systems. Decis Support Syst 23, 175-188 (1998)

56. Reinig, B.A., Shin, B.: the dynamic effects of group support systems on group meetings. J Manag Inf Syst 19, 303-325 (2002)

57. Huang, W., Li, D.: Opening up the black box in GSS research: explaining group decision outcome with group process. Comput Human Behav 23, 58-78 (2007)

58. Vathanophas, V., Liang, S.Y.: Enhancing information sharing in group support systems (GSS). Comput Human Behav 23, 1675-1691 (2007)

59. Lim, J., Guo, X.: A study of group support systems and the intergroup setting. Decis Support Syst 45, 452-460 (2008)

60. Shim, J.P., Warkentin, M., Courtney, J.F., Power, D.J., Sharda, R., Carlsson, C.: Past, present, and future of decision support technology. Decis Support Syst 33, 111-126 (2002)

61. Ackermann, F., Eden, C.: contrasting single user and networked group decision support systems for strategy making. Gr Decis Negot 10, 47-66 (2001)

62. Limayem, M., Banerjee, P., Ma, L.: Impact of GDSS: Opening the black box. Decis Support Syst 42, 945-957 (2006) 


\section{References}

1. Pluciński, M.: Polskie porty morskie w zmieniającym się otoczeniu zewnętrznym. CeDeWu, Warszawa (2013)

2. Ducruet, C., Cuyala, S., Hosni el, A., Kosowska_Stamirowska, Z.: Co-evolutionary dynamics: ports and cities. In: Ducruet, C. (Ed.), Maritime Networks: Spatial Structures and Time Dynamics, Routledge Studies in Transport Analysis, pp. 351-373. Routledge, Oxon, New York (2016)

3. Talley, W.K.: Ports in Theory. In: Talley, W.K. (ed.) The Blackwell Companion to Maritime Economics, pp. 473-490. Wiley-Blackwell, Chichester (2012)

4. Ducruet, C.: The port city in multidisciplinary analysis. In: Allemay, J., Brutomesso, R. (eds.), The Port City in the XXIth Century: New Challenges in the Relationship between Port and City, pp. 32-48. Venice RETE Association \& International Centre for Cities on Water (2011)

5. OECD: The Competitiveness of Global Port-Cities: Synthesis Report. Merk, O. (ed.) OECD Publishing (2014)

6. Cetin, C.K., Cerit, A.G.: Organizational effectiveness at seaports: a systems approach. Marit. Pol. Mgmt. 37, 195-219 (2010)

7. Rymaniak, J.: Założenia ujęcia systemowego zasobów jako podstawy zarządzania portem. Studium przypadku portu gdańskiego. In: Olszewski, J., Rymaniak, J., Lis, K., Milewska, E. (eds.) Ekonomiczno-społeczne i organizacyjno-techniczne determinanty zarządzania rozwojem lokalnym, Tarbonus Kraków (in paper)

8. Zondag, B., Bucci, P., Gützkow, P., de Jong, P.: Port competition modeling including mari time, port, and hinterland characteristics. Marit. Pol. Mgmt. 37, 179-194 (2010)

9. Klopott, M.: Terminale intermodalne na zapleczu portów morskich-koncepcje i doświadczenia. IJME 31, 211-222 (2011)

10. Młynarczyk, J.: Ze studiów nad prawnym modelem zarządzania polskimi portami morskimi. G.S.P. XXXII, pp. 287-296 (2014)

11. Misztal, K.: Organizacja portów morskich. In: Misztal, K. (ed.) Organizacja i funkcjonowanie portów morskich. Uniwersytet Gdański, Gdańsk (2010)

12. Talley, W.K.: Optimum port throughput. In: Shuguang, L., Jinkai, Y. (eds.) Approaches to Maritime Industrial Economy, pp. 21-32. Economic Science Press, Beijing (2006)

13. Jain, A.K.: Data clustering: 50 years beyond K-means. Pattern Recogn. Lett. 31, 651-666 (2010)

14. van der Lugt, L., Dooms, M., Parola, F.: Strategy making by hybrid organizations: the case of the port authority. RTBM 8, 103-113 (2013)

15. Pieńkowska, B., Rakowski, M., Kuzebski, E.: Analiza stanu infrastruktury w portach rybackich i przystaniach pod kątem potrzeb inwestycyjnych pod kątem dalszych potrzeb inwestycyjnych. Raport z badań. Morski Instytut Rybacki, Gdynia (2012)

16. Lagoudis, I.N., Rice Jr., J.B., Salminen, J.B.: Port investment strategies under uncertainty: the case of a southeast asian multipurpose port. As. J. Sh. Log. 30, 299-319 (2014)

17. Studium rozwoju strategicznego małych portów i przystani morskich w województwie pomorskim. Raport. Actia Forum, Gdynia (2009) 